agricultural progress who find it increasingly difficult to cover the immense scientific literature. It might help them in identifying the separate papers as dealt with in the summary, that runs to thirteen pages, if some indication of their place in the review part could accompany the titles.

\section{The Imperial College of Tropical Agriculture}

THE annual report of the Imperial College of Tropical Agriculture, Trinidad, for 1953, by its new principal, Dr. G. A. C. Herklots, contains an account of its staff, administrative organization, teaching and research. Four major research schemes relating to bananas, cacao, sugar and soils are administered by the College, while each of the individual constituent departments pursues appropriate researches. The report (which can be obtained from Trinidad, or from 40 Norfolk Street, London, W.C.2) contains a list of the scientific papers and reports published during the year.

\section{Association of Applied Biologists : Jubilee Confer- ence in London}

THE jubilee conference of the Association of Applied Biologists will be held in the Imperial College of Science and Technology, London, S.W.7, during September 13-15, followed by visits to research stations during September 16-17. The conference will be open to non-members of the Association. In the course of a programme of symposia and lectures covering most of the subjects with which the Association has been concerned, many prominent biologists from Britain and overseas will review the past achievements of applied biology and discuss its present trends and future potentialities. The conference will be under the presidency of Prof. W. Brown, emeritus professor of plant pathology in the University of London. The various sessions will be devoted to papers on the following topics: international co-operation in the field of crop protection; insect pests of stored products; plant viruses and virus diseases; plant growth-regulating substances; problems in applied zoology; soil-borne pests and diseases; education and extension services in applied biology ; crop protection; forecasting and assessment. of plant diseases; and plant nematodes. Three general lectures will be given in the evenings at 5 p.m. as follows : September 13, Prof. E. C. Stakman (emeritus professor of plant pathology, University of Minnesota), on progress and problems in plant pathology; September 14, Prof. V. B. Wigglesworth (Quick professor of biology, University of Cambridge), on the contribution of fundamental research to applied biology; and September 15, Dr. K. W. Neatby (director of Science Service, Department of Agriculture, Canada), on the application of biological research to Canadian agriculture and forestry. In addition there will be a conversazione on September 14 (6.30-10 p.m.), to which all may attend, including those who are not registered members of the Conference. Admission will be by ticket (price $3 s$. 6d., including buffet supper), obtainable from the honorary programme secretary before August 31. Correspondence about exhibits should be addressed to the honorary conversazione secretary, Dr. W. F. Jepson, Imperial College Field Station, Silwood Park, Sunninghill, Berks. Those wishing to attend the conference should write to the honorary programme secretary before June 30 (registration fee $10 \mathrm{~s}$. for members of the Association, and $£ 1$ for non-members).
The honorary programme secretary is Dr. L. Broadbent, of the Rothamsted Experimental Station, Harpenden, Herts, and the honorary general secretary of the conference is Dr. R. K. S. Wood, of the Botany Department, Imperial College, London, S.W.7.

\section{Wave Research Coastal Engineering : Congress in Grenoble}

THE fifth international congress on wave research coastal engineering, organized by the Council on Wave Research of the Engineering Foundation, will be held in Grenoble at the École Nationale Supérieure d'Electrotechnique et d'Hydraulique during . September 8-11, under the general chairmanship of Dr. M. O. O'Brien, dean of the College of Engineering, University of California. The programme will consist of papers on the following topics: problems of the protection and utilization of maritime coasts ; study of waves and tides; coastal erosion, transport of material in suspension; and the design and construction of marine works. The official languages of the congress will be English and French. Papers may be submitted, not later than June 30 , to either the secretary of the congress, Prof. J. W. Johnson, University of California, Berkeley, Calif., or to the local organizing committee at the Ecole Nationale (44-46 Avenue Félix Viellet, Grenoble). The papers will be limited to 20 minutes (maximum of 12,000 words), and those in French must be accompanied by a summary in English not exceeding 600 words.

\section{Summer Schools of Mathematics in Italy}

THREE summer schools have been organized this year by the Unione Matematica Italiana and are being held at the Villa Monastero, Varenna (Como), on the following subjects: analytic functions and normed rings ; surface area and related topics; and non-linear differential equations. The first school has already started; but the other two are still to come, their dates being August 16-25 and September 15-24, and the closing dates for applications are June 30 and July 31, respectively. The languages used will be English and French; the courses will be limited to twenty-five persons. Application forms and further information can be obtained from the organizing secretary, Prof. Roberto Conti, Istituto Matematico 'U. Dini', Via Alfani 81, Firenze.

\section{Announcements}

ThE Charter Travelling Seholarship of the Pharmaceutical Society of Great Britain has been awarded for 1954-55 to Mr. Ralph Kohn, a demonstrator in the Pharmacology Department, University of Manchester, to enable him to go to Rome to continue his studies in pharmacology. The Scholarship, which is worth $£ 600$, was instituted by the Society to commemorate the centenary of the granting of its Royal Charter in 1843.

The Institution of Structural Engineers has accepted an offer by the Aluminium Development Association of a research scholarship of $£ 400$ a year for two years for research on some aspect of the application of aluminium alloys to structures; the scholarship will be awarded in alternate years. The first award will be made this year, tenable from the beginning of next October, and entries for the scholarship close on July 15. Entry forms and further information can be obtained from the Secretary of the Institution of Structural Engineers, 11 Upper Belgrave Street, London, S.W.1. 